\title{
Easy Access to Cell Surface Oligosaccharide Mimics: Carbohydrate Module Approach
}

\section{簡便な細胞表面オリゴ糖鎖ミミックの構築法：糖鎖モジュール化法によるアプローチ}

\author{
Nishida, Yoshihiro*; Dohi, Hirofumi; and Kobayashi, Kazukiyo \\ Department of Molecular Design \& Engineering, Graduate School of Engineering, \\ Nagoya University, Furo-cho, Chikusa-ku, Nagoya 464-8603, Japan \\ FAX: 81-52-789-2528, E-mail:nishida@mol.nagoya-u.ac.jp
}

Key Words: oligosaccharide mimics, sialyl Lewis ${ }^{X}$, Shiga toxins, galactosyl transferases, carbohydrate module

\begin{abstract}
Obviously, human oligosaccharides and their mimics possess high potential in applications to medicines and biomaterials. On the other hand, it holds true that the high potential stems from the rather complicated and labile chemical structures. Therefore, it is of major significance to elucidate the key structures encoded in the oligosaccharides for making effective "minimization" and "functionalization." Moreover, the glycosidic linkages labile to acids and glycosidases may give problems to practical applications. In this review, we wish to describe our mimetic design of the cell surface oligosaccharides based on "key carbohydrate modules" and "carbohydrate module method."
\end{abstract}

要 約

ヒトに発現するオリゴ糖及びそのミミックが医薬品や生体 材料への応用に対して高いポテンシャルを有することは明らか である。その一方で、そのポテンシャルが複雑で不安定な化学 構造から由来することも確かである。よってオリゴ糖の鍵構造 を明らかにすることは、効果的な「構造の最小化」及び「機能 化」を施す上で重要である。さらにグリコシド結合は酸やグリ コシダーゼに対して不安定であるため、応用面で問題をもたら す。本レビューでは、筆者らが行ってきた「鍵糖鎖モジュール 化」と「糖鎖モジュール化法」の概念に基づいた糖鎖ミミック の設計について述べる。

\section{A. Introduction}

Human cell surface oligosaccharides bound to glycoproteins and glycolipids serve as ligands of many types of carbohydrate-binding proteins involving, for example, microbial adhesion proteins and toxins. This means that the cell surface oligosaccharides provide lead compounds that are promising for developing "sugar-based" medicines and bio-probes in materials. Among them, many efforts have been directed to the mimic design of sialyl Lewis ${ }^{\mathrm{X}}\left(\right.$ (Lewis $^{\mathrm{X}}$ ) and the related sialyl oligosaccharides involved in interactions with selectins leading to inflammation and metastasis. The designed artificial selectin ligands and inhibitors to sialidases and CMP-Neu5Ac transferases have high potential in biochemical and medicinal applications. From a viewpoint of the sugar-based medicines and biochemicals, intense interest has been directed to the speciesspecific interaction of microbial adhesion proteins and toxins with the host cell oligosaccharides. For example, Influenza viruses express both hemagglutinins and sialidases, which are used at the respective stages of adhesion to the host cell and budding from the host cells. Therefore, inhibitory reagents to these viral proteins function potentially as anti-influenza reagents (1). Globotriaoside (Gb3) and the related $\alpha 1$,4-galactobiosides (Gb2) are recognized highly specifically by Shiga toxins (Stx-1 and

\section{A. はじめに}

糖タンパクや糖脂質としてヒト細胞表面に発現するオリゴ 糖鎖は、細菌由来の接着タンパク質や毒素のような糖結合タン パク質のリガンドとして働く。このことは、細胞表面のオリゴ 糖が「糖鎖ベース」の医薬品や生体プローブを開発するための リード化合物となりうることを意味する。特に、炎症やガン転 移を誘発するセレクチンファミリーと相互作用するシアリルル イスX $\left(\right.$ sLewis $\left.^{\mathrm{X}}\right)$ や関連するシアロオリゴ糖に対するミミックデ ザインが数多く行われてきた。その中で設計された人工セレク チンリガンドや、シアリダーゼ及びシアリルトランスフェラー ゼに対する阻害剤は、生化学あるいは医療分野における応用性 が高い。また糖鎖べースの医薬品や生化学薬品の開発という観 点から、ホスト細胞のオリゴ糖鎖と特異的に相互作用する微生 物由来の結合夕ンパク質や毒素に高い関心が注がれてきた。例 えば、インフルエンザウィルスはへマグルチニンとシアリダー ゼを発現し、ホスト細胞への接着・脱離を行っている。それゆ え、これらのウィルスタンパク質に対する阻害剂は抗インフル エンザ薬として機能する(1)。グロボトリオース (Gb3)や $\alpha 1,4-$ ガラクトビオシド $(\mathrm{Gb} 2)$ を有する糖鎖は、大腸菌 O-157 やその 関連株によって産生される志賀毒素 (Stx-1, Stx-2) によってきわ 
Stx-2) of E. coli O-157 and the related strains. Multivalent Gb3 models have potential activity to bind to the Shiga toxins and block their infectious activity.

From a viewpoint of the "sugar-based" biomaterials, intense interest is directed to nano- to micro-sized glycomaterials in the form of tips, arrays, and particles. They can be potentially used for sensing infectious microbes and toxins leading also to diagnosis of infectious diseases. For example, glyco-tips made of Gb3 self-assembled monolayer and Gb2 Langmuir-Blodgett film are applied to quartz-crystal microbalance (QCM) systems for easy and discriminative analyses of Stx-1 and Stx-2 $(2,3)$.

Obviously, the human oligosaccharides and their mimics possess high potential in applications to medicines and biomaterials. On the other hand, it also holds true that the high potential stems from the rather complicated but defined structures composed of different sugar residues and linkages. In the case of 6-O-sulfo sLewis ${ }^{\mathrm{x}}$, which serves as the most plausible L-selectin ligand, as well as glycosaminoglycans such as heparan sulfates, alternative functional groups in addition to the complicated oligosaccharide structures may have a key role for biological activities. Moreover, it is of importance for the mimic design that the recognition events in nature are based on multivalent interactions associated with glycoproteins and glycolipids. Actually, the binding affinity of free oligosaccharides is enhanced significantly in forms of multivalent models. Therefore, for blocking the receptor proteins such as the selectins and the bacterial toxins, an appropriate functionalization is required.

The main problems in applying the cell surface oligosaccharides may arise from the difficulty in supplying them in sufficient amounts. Therefore, it is of major significance to elucidate the key structures encoded in the targeting oligosaccharides for making effective "minimization." Additionally, an effective "functionalization" must be conducted taking the geometry of binding sites and subunit structures of the receptor proteins into account. Moreover, the glycosidic linkages labile to acids and glycosidases may give critical problems to practical applications.

\section{B. Design of Oligosaccharide Mimic}

Considering the problems in supplying cell surface oligosaccharides such as sLewis ${ }^{\mathrm{x}}$ and globosides in sufficient amounts as well as in their low chemical stability, chemical modifications and artificial design will be of key investigative issue in coming studies. For simple saccharides such as those carrying D-glucose (Glc) and lactose (Lac) residues, the functional modifications can be performed in variable ways. For instance, as a popular way for solving the problem of low chemical and enzymatic stability, natural $O$-glycosidic linkages are replaced with $C$ - (4-8) and $S$ - (9-11) linkages. Alternatively, a hydroxyl group at the $\mathrm{C}-2$ position is replaced with an electronwithdrawing fluorine atom $(12,13)$. The modified compounds may have chemical structures of carbohydrate analogues and
めて特異的に認識される。多価 $\mathrm{Gb} 3$ モデルは志賀毒素に対して 結合活性を有し、その感染をブロックする。

糖鎖をべースとした生体材料の開発において、チップ、ア レイ、微粒子という形でナノもしくはマイクロサイズ化された 糖鎖材料が注目を集めてきた。これらは感染性微生物や毒素の 検出、そして感染症の診断に用いられている。例えば、Gb3の 自己組織化膜や Gb2 の LB 膜は、簡便かつ高感度にStx-1 と Stx2を検出する水晶発振子システムに応用されている $(2 、 3)$ 。

ヒトに発現するオリゴ糖及びそのミミックが、医薬品や生 体材料への応用に対して高いポテンシャルを有することは明ら かである。一方、そのポテンシャルが異なる糖残基や結合様式 で構成されたかなり複雑だが明確にされた構造に由来すること も確かである。現在最も有望な L-セレクチンリガンドとされる

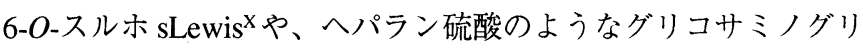
カンの場合、複雑なオリゴ糖鎖の構造に加えて別の官能基が生 理活性上重要な役割を有する。さらに糖鎖ミミックの分子設計 において、自然界における認識機構は糖タンパク質や糖脂質に よる多価相互作用に基づいているという事実は重要である。実 際に、モノメリックなオリゴ糖鎖の結合親和性は多価モデルを 形成することで有意に増幅される。ゆえに、セレクチンや細菌 毒素のようなレセプタータンパクをブロックするには適切な機 能化が必要である。

細胞表面糖鎖を応用する上での大きな問題点は、十分な量 を供給することが難しいことである。よって、標的とするオリ ゴ糖鎖の鍵構造を見つけることは、そのミミック設計における 効果的な「最小化」に扔いてきわめて重要である。加えて、レ セプタータンパクの結合部位とサブユニットの構造をそれぞれ 考慮に入れ、効果的な「機能化」を施さなければならない。さ らに、グリコシド結合が酸やグリコシダーゼに対して不安定で あることが、実際に応用する段階で重大な問題点となりうる。

\section{B. オリゴ糖鎖ミミックの設計}

sLewis ${ }^{x}$ やグロボ系糖鎖のような細胞表層のオリゴ糖を供給 する場合、その供給量及び不安定性が問題となる。ゆえに、そ の化学修飾や人工デザインは将来有望な研究課題である。D-グ ルコースやラクトース骨格を有するような単純な糖に対して は、様々な方法で機能修飾を施すことができる。例えば、化学 的条件下及び酵素に対する不安定性を解決する一般的な方法と して、天然型である $O$-グリコシド結合を $C$-グリコシド結合 (48)、または $S$-グリコシド結合 (9-11) に置換することが挙げられ る。別の方法として、C-2 位の水酸基を電気吸引性基である フッ素原子に置き換える方法もある(12、13)。このように修飾さ れた化合物は糖鎖アナログもしくは 5-Cカルバ糖のような疑似 
pseudo-sugars like 5-C carba-sugars and potentially serve as glycosidase inhibitors.

For higher oligosaccharides, these chemical modifications must be carried out in combination with glycosylation reactions using modified saccharides as either the glycosyl donor or the acceptor. The concept of the mimetic design involves also a broader change of the targeting oligosaccharides. For example, the sugar skeleton may be replaced with amino acids and cyclohexane derivatives to construct artificial glycopeptides and other glycoconjugates.

From the aspect of the mimetic synthesis, the sLewis ${ }^{x}$ antigen is one of the most extensively studied oligosaccharides. This is a common ligand of three types of selectins (E-, P-, and L-selectins). This means that the sLewis ${ }^{\mathrm{X}}$ structure gives a major basis to drug design of anti-inflammatory and anti-cancer reagents.

From a viewpoint of synthetic chemistry, there are some difficulties in constructing the $\alpha$-Neu5Ac-(2-3)- and $\alpha$-Lfucopyranosyl- $(1,4)$ linkages in the tetrasaccharide structures of compounds 1 and 2 (Fig. 1). In these mimetic approaches, the sialyl linkage is replaced with simpler carboxymethyl $\left(-\mathrm{CH}_{2}-\right.$ $\left.\mathrm{COO}^{-}\right)$and $\mathrm{O}$-sulfate $\left(-\mathrm{OSO}_{3}^{-}\right)$groups. These designs are based on X-ray diffraction data of sLewis ${ }^{\mathrm{X}}$ and E-selectin complex, which has disclosed that the carboxylate anion of the sLewis ${ }^{\mathrm{X}}$ provides a major binding interaction with this protein $(14,15)$.

For the $\alpha$-L-fucoside that also gives a major interaction, Wong et al. applied $C$ - $\alpha$-L-fucosyl or $C$ - $\alpha$-D-mannosyl linkages to provide artificial $\alpha$-L-fucoside-based glycopeptides as selectin blockers ( $\mathrm{IC}_{50}=0.1 \mathrm{mM}$ for E-selectin) (16). Ishida and Kiso et al. designed 3-sulfo-galactoside carrying the $\alpha$-L-fucoside at the $O-2$ position and pseudo-ceramide as the aglycon (100\% inhibition at $0.3 \mathrm{mM}$ for P-selectin, and $99 \%$ for L-selectin) (17). Our group used allyl $\alpha$-L-fucopyranoside for easy assembly of an acyclic sLewis ${ }^{\mathrm{X}}$ mimic 3 (18). Kondo et al. designed $\alpha-\mathrm{L}-$ fucopyranosyl dipeptides (Ser-Glu) and simpler selectin antago-

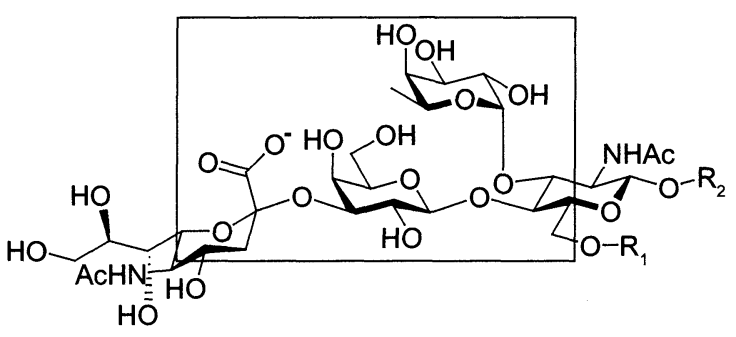

$$
\begin{aligned}
& \text { Sialyl Lewis }{ }^{\mathrm{x}} \text { tetrasaccharides } \\
& \left.1 \text { (sialyl Lewis }{ }^{\mathrm{X}}\right): \mathrm{R}_{1}=\mathrm{H} \\
& 2\left(6-O \text {-sulfo sialyl Lewis }{ }^{\mathrm{x}}\right): \mathrm{R}_{1}=\mathrm{SO}_{3}
\end{aligned}
$$

糖の化学構造を持ち、グリコシダーゼの阻害剤としてよく機能 する。

長鎖オリゴ糖に対する化学修飾は、機能化された糖鎖と、 糖供与体もしくは受容体を用いたグリコシル化反応を組み合わ せて行わなければならない。糖鎖骨格をアミノ酸やシクロへキ サン誘導体に置き換えて人工糖ペプチドや他の糖コンジュゲー トを構築するように、ミミック設計のコンセプトは標的分子を 大幅に改変することもある。

ミミック合成という観点からいえば、 sLewis ${ }^{x}$ 抗原は最も幅 広く研究されたオリゴ糖鎖の一つである。sLewis ${ }^{x}$ 抗原は三種の セレクチン (E-、P-、L-セレクチン) に対する共通のリガンドであ るため、その構造は抗炎症剂や抗がん剂の薬物設計における基 本骨格となっている。

化学合成において sLewis $^{x}$ 四糖 1 (図 1) の $\alpha$-シアリル結合 と $\alpha$-L-フコシド結合の構築は困難を伴うため、ミミックアプ ローチによってシアル酸は単純なカルボキシメチル基 ( $\left.\mathrm{CH}_{2} \mathrm{CO}_{2}^{-}\right)$や $O$-硫酸基 $\left(-\mathrm{OSO}_{3}^{-}\right)$に置換され、シアリル結合を持 たない sLewis $^{\mathrm{X}}$ ミミックの開発へと結びついた。このミミックデ ザインは sLewis ${ }^{\mathrm{X}}$-E-セレクチン複合体の X 線回折デー夕によっ て、sLewis $\mathrm{x}$ のカルボキシル基のアニオン部位がセレクチンとの 相互作用に重要であることが明らかにされたという事実を基に 達成された $(14 、 15)$ 。

sLewis $^{\mathrm{x}}$ のカルボキシル基と同様にセレクチンとの相互作用 に重要な $\alpha$-L-フコースについても、Wong らは $\alpha$-L-フコシル結 合の代わりに $C-\alpha-\mathrm{L}-$ フコシル及び $C-\alpha-\mathrm{D}-$ マンノシル結合を用い ることによって、 $\alpha$-L-フコシドをべースとした人工糖ぺプチド セレクチンブロッカーを開発した $\left(\mathrm{IC}_{50}=0.1 \mathrm{mM}\right.$ for E-selectin)

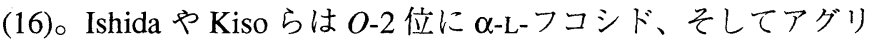
コン部位に疑似セラミドを導入した $3-O$-スルホガラクトースを 設計した (100\% inhibition at $0.3 \mathrm{mM}$ for P-selectin, and $99 \%$ for Lselectin) (17)。我々のグループは、アリル $\alpha$-L-フコピラノシド

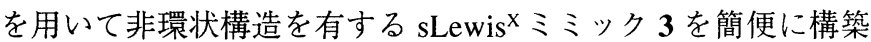
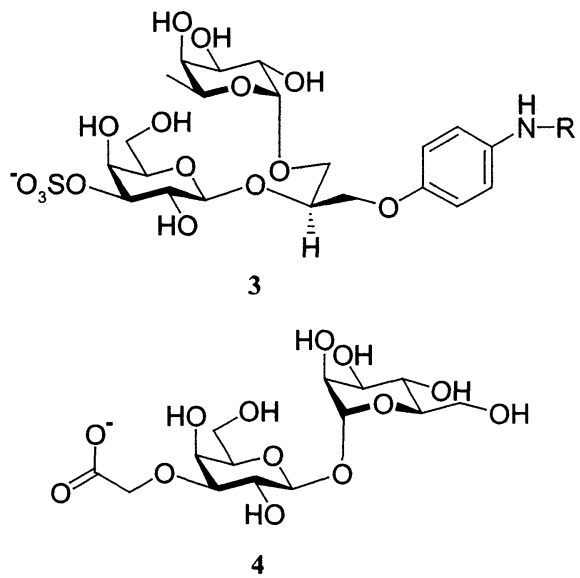

Fig. 1. Structures of sialyl Lewis ${ }^{\mathrm{x}}$ tetrasaccharide and their mimetics. 
nists carrying an aromatic group (43\% inhibition at $30 \mu \mathrm{M}$ for P-selectin) (19).

The designed sLewis ${ }^{\mathrm{x}}$ mimics, giving structural features largely different from that of the natural structure, serve as potent selectin blockers. This means that the apparently complicated structures of the cell surface oligosaccharides can be remodeled into much simpler mimic compounds. For the mimic design, X-ray crystalline or library assembly of synthetic compounds provided useful bases to determine the key recognition structures encoded in natural structures.

\section{Biological Potential of Trehalose 1,1-Linkages}

For the design of the functional oligosaccharide mimics tolerable to acidic and enzymatic conditions, the use of trehalose 1,1-linkages seems to be promising. Natural trehalose is a symmetric non-reducing disaccharide having $\alpha 1,1 \alpha$-linked Dglucose disaccharide. By using enzymes and starches as natural sources, this disaccharide is manufactured by a Japanese Industry (20). As compared with $\alpha 1,3-$ and $\alpha 1,4$-linked glycosides, the trehalose linkage is considered to have higher chemical and enzymic stability. Thus, it has high potential in applications to medicines and materials.

Several notable biological effects have been disclosed for the trehalose. For example, a recent study has evidenced that the trehalose shows positive effects on delaying the progress of symptoms of Huntington disease associated with the aggregation of polyglutamines in human brains (21). Trehalosamines carrying amino groups in the trehalose skeleton serve as aminoglycoside-based antibiotics (22). Heparin analogues carrying the 1,1-linkage at the reducing end are also designed by a group of Hoffmann-La Roche (23). Wong et al. designed dissymmetric $\alpha$-D-mannosyl-(1,1)- $\beta$-D-galactosyl linkage 4 (Fig. 1 ) as a mimic of the sLewis ${ }^{X}(24)$. There, such a dynamic structural change is involved that the sLewis ${ }^{\mathrm{X}}$ sequence is replaced with the 1,1-linkage.

Expecting the high biological potential of the trehalose and the related non-reducing 1,1-linked disaccharides, our group has also designed oligosaccharide mimics based on the skeleton of the 1,1-linked disaccharide. We described a close structural
した (18)。Kondo らは $\alpha$-L-フコピラノシルジペプチド(Ser-Glu) や芳香族官能基によって構成された非常に単純な構造を有する セレクチンアンタゴニストを設計した $(43 \%$ inhibition at $30 \mu \mathrm{M}$ for P-selectin) (19)。

これらの sLewis ${ }^{\mathrm{x}}$ ミミックは天然型のものとは非常に異なる 構造特性を有するが、セレクチンブロッカーとして働く。これ は細胞表層オリゴ糖鎖の複雑な構造が、もっと単純なミミック 化合物によって再構築されることを意味する。ミミックデザイ ンにおいてX 線結晶解析や合成化合物のライブラリーは、天然 型糖鎖に含まれる鍵となる認識構造を決定するときに有益な礎 をもたらす。

\section{C. トレハロース 1,1-結合の生物的ポテンシャル}

酸性及び酵素的条件下に耐えうる機能的オリゴ糖鎖ミミッ クを構築するためには、トレハロース 1,1 結合は有用であるよ うだ。天然のトレハロースは、二分子のグルコースが $\alpha 1,1 \alpha$ 結 合した対称性の非還元性二糖である。日本の企業 (林原研究所) が酵素とデンプンを原料として用いたトレハロースの大量生産 を行っている $(20)$ 。 $\alpha 1,3$ もしく $\alpha 1,4$ 結合型糖鎖と比較する と、トレハロース結合は化学的及び酵素的に安定であると見な されている。よって、トレハロース結合は医薬品や生体材料へ の応用性が高い。

注目に值するいくつかの生理活性がトレハロースから見出 されている。例えば最近の研究により、トレハロースがヒト脳 内でのポリグルタミン酸の集積によって引き起こされるハンチ ントン氏病の病状の進行を積極的に遅らせる効果を持つことが 明らかになった (21)。また、トレハロース骨格中にアミノ基を 有するトレハロサミンはアミノ糖べースの抗生物質として働く (22)。Hoffmann-La Roche の研究グループは還元末端に 1,1 結合 を有するへパランアナログを設計した (23)。Wong らは非対称 性の $\alpha$-D-マンノシル-(1,1)- $\beta$-D-ガラクトシル結合を持つ 4 (図 1) を sLewis ${ }^{\mathrm{x}}$ ミミックとして設計した (24)。このミミックデザイ ンにおいては、sLewis ${ }^{\mathrm{x}}$ の配列を 1,1 結合に置き換えるような非 常にダイナミックな構造転換を伴っている。

トレハロースや関連した非還元性 1,1 結合型糖鎖の高い生 理活性を期待して、我々も 1,1 結合型二糖骨格を基にオリゴ糖 鎖ミミックを設計した。 $\mathrm{Gb}_{2}$ 糖鎖 5 とトレハロース 7 (図 2) が

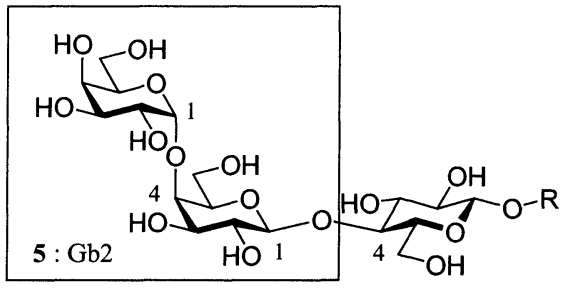

6: Gb3

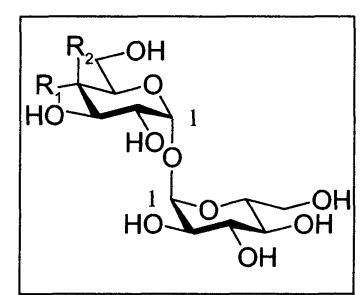

7 (Treahlose): $\mathrm{R}_{1}=\mathrm{OH}, \mathrm{R}_{2}=\mathrm{H}$

8 (Galacto-type Trehalose): $\mathrm{R}_{1}=\mathrm{H}, \mathrm{R}_{2}=\mathrm{OH}$

Fig. 2. Structural homology in globosyl Gb2 and galacto-type trehalose. 
homology between $\mathrm{Gb} 25$ and trehalose 7 (Fig. 2), meaning that the trehalose linkages can be applied as artificial ligands of the Shiga toxins produced by $E$. coli.

The Shiga toxins (Stx-1 and Stx-2) are proteins comprising one toxic A-subunit and five receptor binding B-subunits. Both Stx-1 and Stx-2 recognize the neutral Gb2 and Gb3 oligosaccharides, which exist as glycosyl ceramides in human cell surfaces. There have been extensive studies on the molecular design of artificial ligands possessing simple structures and high activity for blocking the toxin-host cell adhesion. Replacement of the ceramide group with simpler groups was the central objective. Previously, we prepared artificial glycopolymers carrying the $\mathrm{Gb} 3$ along acrylamide polymer in clusters, which showed potent neutralization activity against the Shiga toxin (Stx-1) $\left(\mathrm{CD}_{50}=1-5 \mathrm{ng} / \mathrm{mL}\right.$ for Stx-1, ACHN cells $)(25,26)$. The Gb3carrying dendrimers as well as the glycopolymers designed by Matsuoka et al. $\left(\mathrm{IC}_{50}=50 \mathrm{nM}\right.$ for Stx-1, and $820 \mathrm{nM}$ for Stx-2, Vero cells) $(27,28)$ and the starfish models by Kitov et al. $\left(\mathrm{IC}_{50}=\right.$ $1.2 \mu \mathrm{M}$ for Stx-1, and 1.6 $\mu \mathrm{M}$ for Stx-2, Vero cells) (29) showed neutralization activity to both Stx-1 and Stx-2. It was also found that an analogous polymer carrying isoGb3 [ $\alpha$-D-Gal- $(1,3)-\alpha-$ D-Gal-(1,4)- $\beta$-D-Glc] showed no activity (26). It is obvious that the Gb3-toxin interaction is based on a high species-specific interaction. Uzawa et al. (2) and Miura et al. (3) applied the specific interaction to develop Shiga-toxin detecting systems utilizing the $\mathrm{Gb} 2$ and $\mathrm{Gb} 3$ saccharides, respectively. Thus, the natural $\mathrm{Gb} 2$ and $\mathrm{Gb} 3$ saccharides themselves have high values for medicines and biomaterials. Therefore, extensive efforts are being directed to their practical syntheses based on chemical (30-32) and biological processes (33) in addition to isolation and modification of ones from natural sources (34).

However, an effective mimic of the galactobiosyl $\alpha 1,4-$ linkage had not been designed. This was ironic since the practical synthesis of the Gb2 and Gb3 is hampered by the difficulty in constructing the key linkage. It can be easily noticed that the trehalose $\alpha 1,1 \alpha$-linkage has a molecular topology analogous to that of the $\mathrm{Gb}_{2}$ linkage as can be seen in Fig. 2. A critical difference arises from the configuration at $\mathrm{OH}-4$, which should be
非常に似通った構造相関性を有している、すなわち大腸菌が生 産する志賀毒素に対する人エリガンドにトレハロース結合を適 用できることを報告した。

志賀毒素 (Stx-I, Stx-II) は毒性を示す 1 つの A サブユニット

と、糖鎖結合部位を有する 5 つの B サブユニットから構成され るタンパク質である。Stx-I と Stx-II はともに、ヒト細胞上に糖 セラミドの形で存在する中性糖脂質である $\mathrm{Gb} 2$ 及び $\mathrm{Gb} 3$ を認 識する。現在までに、単純な構造を持ちなおかつ毒素と宿主細 胞の接着を強く阻害する人エリガンドの分子設計が行われ、特 にセラミド部位を簡略化することに重点が置かれてきた。我々 はアクリルアミドポリマー上に $\mathrm{Gb} 3$ 糖鎖をクラスター化した人 工糖鎖高分子を調製し、志賀毒素 (Stx-1) に対して強力な中和活 性を示すことを先駆けて報告した $\left(\mathrm{CD}_{50}=1 \sim 5 \mathrm{ng} / \mathrm{mL}\right.$ for Stx-1, ACHN cells) $(25 、 26)$ 。MatsuokaらはGb3 糖鎖を有するデンドリ マー及び人工糖鎖高分子を設計し $\left(\mathrm{IC}_{50}=50 \mathrm{nM}\right.$ for Stx-1, and 820 nM for Stx-2, Vero cells) (27、28)、Kitov らはヒトデ型モデルがStx1 及び Stx-2 両毒素に対して中和活性を有することを示した $\left(\mathrm{IC}_{50}=1.2 \mu \mathrm{M}\right.$ for Stx-1, and $1.6 \mu \mathrm{M}$ for Stx-2, Vero cells) (29)。isoGb3 糖鎖 [ $\alpha$-D-Gal-(1,3)- $\alpha$-D-Gal-(1,4)- $\beta$-D-Glc] を組み込んだアナログ ポリマーが志賀毒素に対して中和活性を全く示さなかったこと から、 Gb3 糖鎖と毒素の相互作用は高い基質特異性に基づいて いることは明らかである (26)。Uzawa らや Miura らは、この高 い基質特異性を利用して $\mathrm{Gb} 2$ または $\mathrm{Gb} 3$ 糖鎖を用いた志賀毒 素検出システムをそれぞれ開発した $(2 、 3)$ 。このように、天然の $\mathrm{Gb} 2$ 及び $\mathrm{Gb} 3$ 糖鎖自身も医薬品や生体材料の開発において高い 生理活性がある。よって、化学的及び生化学的手法、さらには 天然物からの単離・修飾による $\mathrm{Gb} 2$ 及び $\mathrm{Gb} 3$ 糖鎖の大量合成 法の開発が活発に行われてきた(30-34)。

しかしながら、ガラクトビオシル $\alpha 1,4$ 結合の効果的なミ ミックは設計されていなかった。皮肉にも鍵となる結合構築の 難しさが、 $\mathrm{Gb} 2$ 及び $\mathrm{Gb} 3$ 糖鎖の大量合成の際に足かせとなって いる。図 2 からわかるように、トレハロース $\alpha 1,1 \alpha$ 結合の分子 トポロジーはガラクトビオシル $\alpha 1,4$ 結合のものと似ていること に容易に気付くことができる。両者の決定的な違いは、志賀毒 素との結合にはアキシャルであるべき 4 位の水酸基である。そ

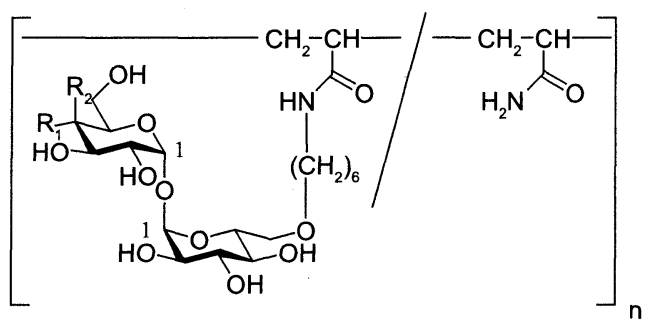

9 (Treahlose): $\mathrm{R}_{1}=\mathrm{OH}, \mathrm{R}_{2}=\mathrm{H}$

10 (Galacto-type Trehalose): $\mathrm{R}_{1}=\mathrm{H}, \mathrm{R}_{2}=\mathrm{OH}$

Fig. 3. Multivalent models of trehalose and galacto-type trehalose. 
axial for the Shiga toxins. Accordingly, a galactose-type trehalose was designed as an artificial toxin ligand having an advantageous property as we have mentioned above (35). By different biological assays, we have found that the galactose-type trehalose becomes a promising substitute for the globosyl $\alpha 1,4-$ linkage. The neutralization activity of the galactose-type trehalose to Shiga-toxins, particularly to Stx-2, was negligibly weaker than that of the natural $\mathrm{Gb} 2$ and $\mathrm{Gb} 3$ ligands. On the other hand, the activity was integrated in a form of glycopolymer 10 up to $90 \%$ of that of a related $\mathrm{Gb} 2$ polymer (MIC $=4.1 \times 10^{-5} \mathrm{M}$ for Stx-1, Hemagglutinin inhibition assay) (Fig. 3). A glycopolymer 9 carrying trehalose in clusters showed little activity (MIC $>5.7$ $\times 10^{-2} \mathrm{M}$ for Stx-1, Hemagglutinin inhibition assay).

Our interest in using the trehalose linkages as the mimic of natural oligosaccharides stems from the discovery of $\beta 1,1$ galactosyl transferase reactions catalyzed by bovine $\beta 1,4-$ galatosyl transferase. When 3-acetamido-3-deoxy-D-glucose (DGlc-3-NAc) was used as the acceptor substrate, the $\beta 1,1 \beta$-linked disaccharide of $\beta$-D-Gal-(1,1)- $\beta$-D-Glc-3-NAc 12 was constructed exclusively (Fig. 4) (36).

The observed abnormal reaction indicated that the mammalian enzyme recognizes a partial structure in the acceptor substrates, which is made of a sequence of 3-acetamido-1,2propanediol. This sequence is involved in both natural GlcNAc and the synthetic D-Glc-3-NAc ( $N$-acetyl kannosamine) to direct the bovine enzyme to perform natural $\beta 1,4-$ and $\beta 1,1-$ galctosyl transfer reactions, respectively $(37,38)$. This enzyme does not utilize L-series sugars such as L-Glc and L-Xyl, while the enzyme turns to accepting their 1-acetamido derivatives, i.e., L-Glc-1-NAc and L-Xyl-1-NAc, to give $\beta(1,3)$-linked disaccharides, exclusively. Even for an acyclic 3-acetamido-1,2propanediol, this enzyme gives the corresponding $\beta$-D-galactosyl product in a regio- and enantiospecific way, indicating a major site-directed by the key sequence. Here, it is of interest to note that the $\beta$-galactosyl compounds produced have a close topology to $N$-acetyl $\beta$-lactosamine $\mathbf{1 1}$ (LacNAc) and lactose (Fig. 4), suggesting their utility as LacNAc mimics.

We have described that the trehalose and the related 1,1linked saccharides have high biological potential. Toward practical assembly of these treahaloses and multivalent models, several different approaches have recently appeared $(39,40)$. In addition to a chemical approach to the $\alpha 1,1 \alpha$-linked trehaloses
れゆえ、我々はガラクト型トレハロースを上記の有利な性質を 付与した人工志賀毒素リガンドとして設計した (35)。我々は異 なる生理活性試験によって、ガラクト型トレハロースがグロボ シル $\alpha 1,4$ 結合に置換しうることを見出した。その志賀毒素に対 する結合親和性、特に Stx-2 に対しては天然の $\mathrm{Gb} 2$ 及び $\mathrm{Gb} 3$ 糖 鎖に比べて非常に弱かった。しかしながら、ガラクト型トレハ ロースの親和性は糖鎖高分子 10 (図 3) にすることで増幅され、 対応する $\mathrm{Gb} 2$ 糖鎖高分子の $90 \%$ 以上の活性を示した。 $(\mathrm{MIC}=4.1$ $\times 10^{-5} \mathrm{M}$ for Stx-1, Hemagglutinin inhibition assay)。トレハロース を組み込んだ糖鎖高分子9は毒素に対する親和性をほとんど示 さなかった $\left(\mathrm{MIC}>5.7 \times 10^{-2} \mathrm{M}\right.$ for Stx-1, Hemagglutinin inhibition assay)。

我々がトレハロース結合を天然オリゴ糖鎖のミミックとし て使用することに着目した理由は、ウシ由来の $\beta 1,4$-ガラクトシ ルトランスフェラーゼによる $\beta 1,1$-ガラクトース転移反応の発見 に由来する。3-アセトアミド-3-デオキシ-D-グルコース (D-Glc-3$\mathrm{NAc)}$ を受容体基質として用いた場合、 $\beta 1,1 \beta$ 結合した二糖 $\beta$-DGal-(1,1)-B-D-Glc-3-NAc 12 が優先して生成する (図 4) (36)。

この異常な反応は、哺乳類の酵素は受容体基質の一部の構 造、すなわち 3-アセトアミド-1,2-プロパンジオール配列を認識 することを示唆した。この配列は天然の基質である GlcNAc と、 構成基質である D-Glc-3-NAc ( $N$-アセチルカンノサミン)に含ま れ、ガラクトシルトランスフェラーゼに通常の $\beta-1,4$ 転移また は $\beta-1,1$ 転移をそれぞれ誘起する。本酵素は L-グルコースや Lキシロースのような L 糖には用いられなかったが、1-アセトア ミド誘導体、すなわち L-Glc-1-NAc や L-Xyl-1-NAc は $\beta-1,3$ 結 合した二糖を優先的に生成する。本酵素は非環状型の 3-アセ卜 アミド-1,2-プロパンジオールに対しても、位置及び立体選択的 な反応を経て対応する $\beta$-D-ガラクトシル生成物を与える。よっ て、3-アセトアミド-1,2-プロパンジオール構造が、酵素が認識 する主要な特定部位であるといえる。このように合成された $\beta$ D-ガラクトシル化合物は、N-アセチルラクトサミンやラクトー スと似通ったトポロジーを有するため (図 4)、LacNAc ミミッ クとして用いることができる可能性があるため興味深い。

我々はトレハロースや関連した 1,1 結合型糖鎖が高い生物 的ポテンシャルを持つことを述べてきたが、実用的な 1,1 結合 型糖鎖や多価モデルの構築を目指したいくつかの異なるアプ

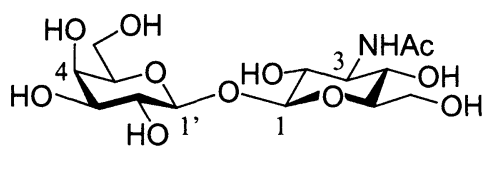

12 ( $\beta, \beta$-Trehalo-type of LacNAc)

Fig. 4. Non-reducing $N$-acetyl lactosamine (LacNAc) mimic 12 derived with bovine lactose synthetase and 3acetamido-3-deoxy-D-glucose (D-Glc-3NAc). 
by Pratt et al. (39), enzymic synthesis of the galactose-type trehalose was reported by Chaen et al. (40). Enzymic assembly of multivalent trehaloses was also reported by Miura et al. (41) The bovine $\beta$-galactosyl enzyme allows us to construct the $\beta(1,1) \beta$-linked saccharides in a regio- and stereospecific manner as we have described. For the dissymmetric $\alpha(1,1) \beta$-linked saccharides, Wong et al. reported a chemical pathway using 1$O$-silyl-protected acceptor sugars $(24,42)$. We expect that these synthetic studies will accelerate practical applications of the 1,1linked saccharides for the "sugar-based" medicines and biomaterials.

\section{Carbohydrate Module Method}

In nature, the cell surface oligosaccharides play their roles in the form of polymers or clusters of natural glycoproteins and glycolipids forming micro domains in cell membrane. This corresponds to the popular case of the carbohydrate receptor proteins possessing subunit structures and thus multiple binding to cause multivalent binding interactions. This means that synthetic carbohydrate molecules can function more effectively in appropriate multivalent forms except for several cases such as those for enzyme inhibitors and antibiotics. Different types of multivalent glycoconjugates have been proposed and applied, which include glycosyl polymers, dendrimers, mono-layers, liposomes, and particles. On the other hand, few models carry the cell surface oligosaccharides or the mimics possessing higher biological potential. An improved synthetic process and methodology

\section{a) Segmentation into} key modules

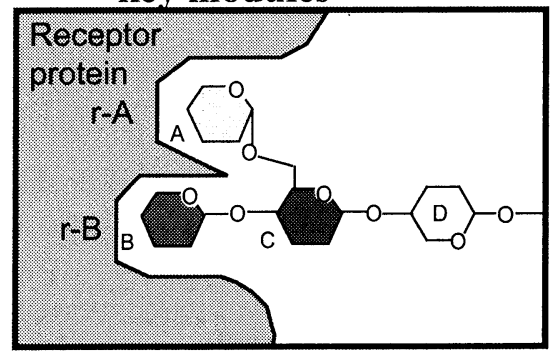

ローチが近年報告されている。Pratt らによる化学的手法による $\alpha 1,1 \alpha$ 結合型糖鎖の合成に加えて (39)、Chaen らはガラクト型 トレハロースの酵素的合成法を報告している (40)。Miura らは 酵素法によるトレハロース多価モデルの構築を報告した (41)。 我々は先に述べたように、ウシ由来の $\beta 1,4-$ ガラクトシルトラン スフェラーゼによる位置選択的かつ立体選択的な方法で $\beta 1,1 \beta$ 結 合型糖鎖を合成することに成功した。非対称性 $\alpha 1,1 \beta$ 結合型糖 鎖については、Wong らは1-O-シリル保護した糖鎖受容体を用 いた化学的経路を報告した $(24 、 42)$ 。これらの合成研究が「糖鎖 ベース」の医薬品や生体材料へ向けた 1,1 結合型糖鎖の実忍用 を加速することを期待したい。

\section{D. 糖鎖モジュール化法}

自然界において細胞表面のオリゴ糖鎖は、糖タンパク質や 糖脂質が細胞膜上でミクロドメインを形成することで高分子ま たはクラスターという形で機能している。すなわちサブユニッ 卜構造を有する糖結合タンパク質の一般的な事例に一致し、 よって複数の結合が多価結合相互作用を誘発する。このこと は、酵素の阻害剤や抗生物質のようないくつかの場合を除い て、合成した糖鎖分子が適切な多価モデルを形成することに よってさらに効果的に機能することを意味する。糖鎖高分子、 デンドリマー、リポソーム、微粒子といった多種の多価糖鎖モ デルが提案及び応用されてきた。その一方で、細胞表面オリゴ 糖鎖や高い生理活性を有するミミック分子を組み込んだモデル はほとんど存在しない。このような高レベルの多価糖鎖モデル の実践的な構築には、合成化学的なプロセスや手法の改良が強

\section{b) Assembly of key carbohydrate modules}

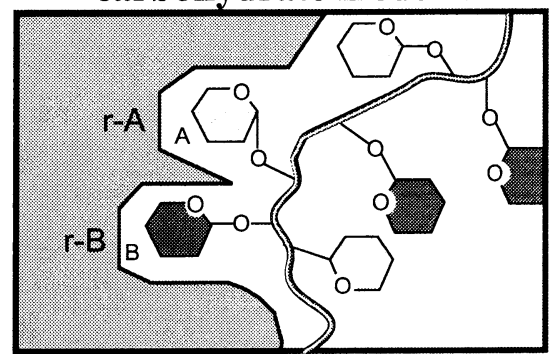

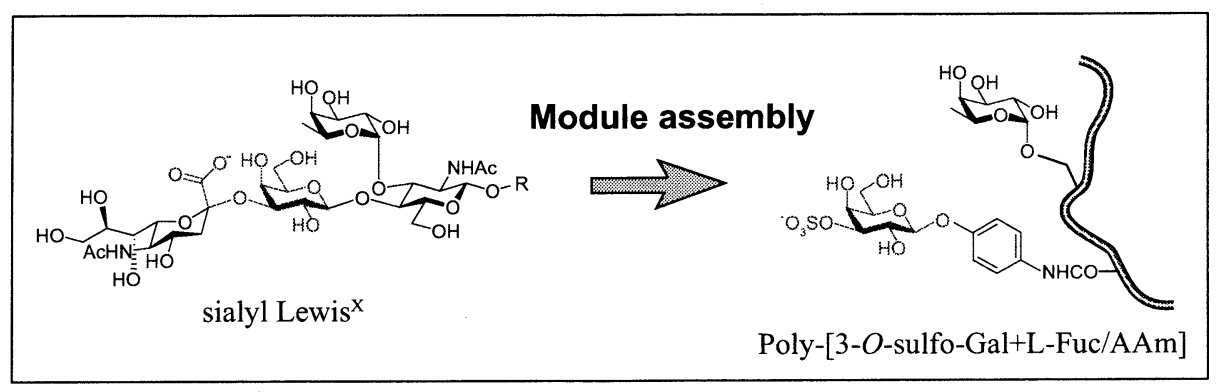

c) Modular assembly of multivalent sialyl Lewis ${ }^{\mathrm{x}}$ mimics

Fig. 5. Concept of the "Carbohydrate Module Method" for easy assembly of multivalent oligosaccharide mimics. 
is strongly desired toward the practical assembly of these higher multivalent glycoconjugates.

In our synthetic study on artificial glycopolymers, we have taken a radical copolymerization approach that may be termed "glycomodule or carbohydrate module approach" (18, 43) (Fig. 5). For example, an acrylamide-based glycopolymer carrying both $\alpha$-L-fucopyranoside and 3-O-sulfo- $\beta$-Dgalactopyranoside along the side chain shows potent activity to block L-selectin/sLewis ${ }^{\mathrm{X}}$ tetrasaccharide adhesion. None of the two glycopolymers carrying one of the two sugars shows notable activity. This means that the observed blocking activity is ascribable to the cooperative effects of the two key glycosides embedded in the acrylamide copolymer. Thus, the radical copolymerization provides a easy and highly effective access to sLewis ${ }^{\mathrm{X}}$ mimics and multivalent models.

For an easy understanding of the "carbohydrate module approach", a binding model between a branching oligosaccharide and the receptor protein may be used (Fig. 5). In this model, the two glycosidic residues of A and B provide the key carbohydrate structures for the receptor protein. Conventional mimic syntheses may target a branching trisaccharide carrying $\mathrm{A}, \mathrm{B}$, and $C$ residues and further its multivalent models (Fig. 5a). The glycomodule approach targets a copolymer- $(\mathrm{A}+\mathrm{B})$ carrying the key glycosides (Fig. 5b). The simple copolymer-( $A+B)$ will gain a certain chance to occupy both of the binding sites and thus exhibit higher activity than the polymers carrying one of the two epitope sugars. This means that the copolymerization between the key glycosyl monomer-A and monomer-B provides a simultaneous methodology for both mimicking a targeting oligosaccharide and assembling the multivalent model (Fig. 5c). As a practical application, we undertook the carbohydrate module approach to mimic assembly of 6- $O$-sulfo sialyl Lewis ${ }^{\mathrm{x}}$ (compound 2 in Fig. 1), that serves as a better ligand of L-selectin than natural compound 1 . The complicated structure was segmented to 3-O-sulfo Lewis ${ }^{\mathrm{x}}$ mimic 3 (Fig. 1) and 6-O-sulfoGlcNAc, which were copolymerized with acrylamide in either an independent or a cooperative manner. Among the glycopolymers, we found that an acrylamide polymer carrying 6- $O$-sulfo-GlcNAc in clusters shows notable blocking activity to the $\mathrm{L}$-selectin $\left(\mathrm{IC}_{50}=3 \mu \mathrm{M}\right.$ for L-selectin). The activity was
く望まれている。

我々は人工糖鎖高分子の合成研究において、ラジカル共重 合を用いる「グライコモジュール化法」もしくは「糖鎖モ ジュール化法」と呼ばれる方法を適用してきた(図 5) (18、43)。

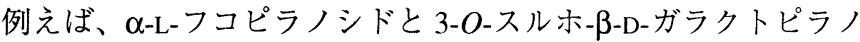
シドを側鎖に有するアクリルアミドベースの糖鎖高分子は、 sLewis ${ }^{x}$ 四糖のL-セレクチンに対する接着を強くブロックする。 この観察されたブロック活性は、アクリルアミドコポリマーに 埋め込まれた二つの鍵糖鎖による協奏効果によるものと説明で

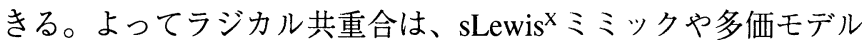
を得るための簡便かつ非常に効果的な手段である。

「糖鎖モジュール化法」をよりわかりやすくするには、枝 分かれオリゴ糖鎖とレセプタータンパクの結合モデルを用いる のがよいだろう (図 5)。従来のミミック合成は、A、B、C 残基を 有する枝分かれ三糖、さらにはその多価モデルをターゲットに している (図 5a)。グライコモジュール化法では鍵となる配糖体 を持つ共重合体 $(A+B)$ を標的にする (図 $5 b)$ 。単純な構造を持 つ共重合体 $(\mathrm{A}+\mathrm{B})$ は結合部位を占有する可能性があるため、1

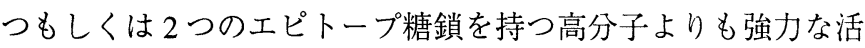
性を持つ。ゆえに、鍵となる配糖体モノマーA とモノマーBの 共重合は、標的オリゴ糖鎖のミミック化と多価モデルの構築と いう二つの操作を同時に可能にする方法であるといえる (困 5c)。実応用に向けて、我々は糖鎖モジュールアプローチによっ て、天然の sLewis $\mathrm{x}$ 四糖 $\mathbf{1}$ より優れた L-セレクチンリガンドで ある 6-O-スルホ sLewis ${ }^{\mathrm{x}}$ のミミック構築に着手した。その複雑 な構造を 3-O-スルホ Lewis ${ }^{\mathrm{x} ミ ミ ッ ク ~} 3$ (図 1) と 6-O-スルホ GlcNAc に断片化し、それぞれ単独もしくは両者を組み合わせて アクリルアミドと共重合を行った。調製した糖鎖高分子の中 で、6-O-スルホ sLewis ${ }^{\mathrm{X}}$ をクスター状に組み込んだアクリルア ミドポリマーがひときわ強いL-セレクチンブロック活性を示し た $\left(\mathrm{IC}_{50}=3 \mu \mathrm{M}\right.$ for L-selectin)。そのブロック活性は二つの鍵配糖 体モジュールを組み込んだ共重合体に匹敵し $\left(\mathrm{IC}_{50}=3 \mu \mathrm{M}\right.$ for Lselectin)、このような単純な糖鎖でも L-セレクチンと強い相互作 用が可能であることがわかった。この結果は少なくとも、6-Oスルホ GlcNAc 骨格が高い生理的ポテンシャルを持つことを明 らかとした。

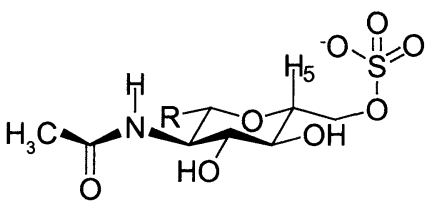

6-O-Sulfo- $\beta-D-G I c N A c 14$

$[\mathrm{R}=\mathrm{O}-$ Aglycon $]$

$\left[\mathrm{R}=\mathrm{CH}(\mathrm{OH}) \mathrm{CH}(\mathrm{OH}) \mathrm{CH}_{2} \mathrm{OH}\right]$

Fig. 6. Structural homology between Neu5Ac 13 and 6-O-sulfo-GlcNAc 14. 
comparable to that of a copolymer carrying both of the two key glycoside modules ( $\mathrm{IC}_{50}=3 \mu \mathrm{M}$ for $\mathrm{L}$-selectin), to suggest that such a simple sugar can provide major interactions with this protein. At least, this result has disclosed that the skeleton of the 6-O-sulfo-GlcNAc has high biological potential.

The strong activity of the glycopolymer carrying 6-Osulfo-GlcNAc was, however, not surprising when a close structural homology between 6-O-sulfo-GlcNAc and Neu5Ac was considered (Fig. 6). Namely, the skeleton of the 6-O-sulfoGlcNAc gives $\mathrm{OH}, \mathrm{NHAc}$, and anionic groups in the stereochemistry similar to those of the Neu5Ac. Thus, the polymer may be capable of occupying the binding sites for both 6- $O$-sulfoGlcNAc and Neu5Ac to induce stronger binding activity than a glycopolymer carrying 3-O-sulfo-Lewis ${ }^{\mathrm{x}}$ mimics in clusters. Schmidt $e t$ al. also applied the relation between GlcNAc and Neu5Ac in their recent study on CMP-Neu5Ac transferase inhibitors (44). It is well known that a WGA lectin recognizes both GlcNAc and Neu5Ac. The seemingly diverse recognition can be rationalized in the same way.

The notable activity of the glycopolymer carrying the 6$O$-sulfo-GlcNAc has evidenced that the 6- $O$-sulfo-GlcNAc possesses high biological potential. In our recent studies, we are examining the potential for the design of sialidase inhibitors, which has been based on the Neu5Ac and Neu5Ac-2-en structures (45). Moreover, the skeleton of 6-O-sulfo-GlcNAc constitutes key carbohydrate modules of glycosaminoglycans like heparan sulfates. This suggests the potential use of the multivalent 6-O-sulfo-GlcNAc as artificial cell matrixes for cell culturing and tissue engineering. Moreover, extensive studies have evidenced a triggering role of the glycosaminoglycans in transforming natural prion proteins into the scrapie prion (46). We speculate that the 6-O-sulfo-GlcNAc and the multivalent models will provide a useful basis to the drugs and materials design.

We proposed the carbohydrate module approach as a novel methodology for mimicking cell surface oligosaccharides and assembling their multivalent models. Thereafter, we recognized that the synthetic methodology enables us to elucidate key carbohydrate-protein interactions and disclose high biological potential in simple sugars and sugar mimics. Though our modular approach is based on radical copolymerization, a similar approach has been undertaken with alternative assembling methods. For example, Patel and Lindhorst used their sugar-based dendrimers for the assembly of different sugars, while Pochechueva and Bovin et al. used polyacrylic acid as the template $(47,48)$. John and Nagi et al. used nano-spheres for the assembly of $\alpha$-L-fucoside and sulfate groups to prepare potent P-selectin ligands (49). Palmacci and Seeberger undertook their modular approach to heparan sulfates (50). Though they are discriminated from each other and also from ours, they seem to be based on a common concept of carbohydrate modules useful for simple and effective design of cell surface oligosaccharide mimics.
6-O-スルホ GlcNAc を持つ糖鎖高分子がこのように高い活 性を示すことは、6-O-スルホ GlcNAc と Neu5Ac の構造的ホモ ロジーを考慮すれば驚くことではない(図 6)。すなわち、6-O-ス ルホ GlcNAc 骨格中の水酸基、 $N$-アセチル基、そしてアニオン 性官能基がNeu5Ac と似た立体化学構造を取っている。よって、 本糖鎖高分子は 6-O-スルホ GlcNAc と Neu5Ac の結合部位を占 有することができ、その結果 3-O-スルホLewis $\mathrm{x}$ をクラスター状 に有する糖鎖高分子よりも強い結合活性を示したのであろう。 Schmidt らも最近のCMP-シアリルトランスフェラーゼ関する研 究において、この GlcNAc と Neu5Ac の関係を利用した。WGA レクチンが GlcNAc と Neu5Ac の両糖鎖を認識することは周知 の事実であるが、多彩そうに見えるこの認識も同様の方法で説 明できる。

この 6-O-スルホ GlcNAc を持つ糖鎖高分子が注目に值する 活性を示したことにより、6-Oスルホ GlcNAc が高い生物的ポ テンシャルを有することが明らかとなった。我々は最近の研究 で、Neu5Ac や Neu5Ac-2-en 構造に基づいたシアリダーゼ阻害 剤の設計にむけた 6-O-スルホGlcNAc のポテンシャルについて 調べている(45)。さらに、硫酸化 GlcNAc はヘパラン硫酸のよう なグリコサミノグリカンの鍵となる糖鎖モジュールである。こ のことは 6-O-スルホ GlcNAc の多価モデルが、細胞培養や組織 工学に用いるための人工細胞マトリックスのような幅広い潜在 的用途があることを示唆している。また数多くの研究によっ て、グリコサミノグリカンがプリオンタンパクからスクラピー タンパクへの変化を誘発する役割を持つことが明らかになった (46)。我々は 6-O-スルホ GlcNAc とその多価モデルが、プリオ ン病に対する薬剤及び材料設計おいて有用な土台となることを 検討している。

我々は、糖鎖モジュール化法を細胞表面オリゴ糖のミミッ ク化及びその多価モデルの構築する新たな方法論として提唱し た。それ以来、我々は化学合成法が糖鎖-タンパク質相互作用に おいて鍵となる相互作用を決定する、そして高い生物学的潜在 能力を有する単純な糖鎖もしくはそのミミックを解明する手助 けとなると認識した。我々のモジュラーアプローチはラジカル 共重合に基づいているが、類似のアプローチも別の構築法に よって遂行されつつある。例えば、Patel と Lindhorstは糖鎖べー スのデンドリマーを異なる糖鎖の構築に用いているのに対し て、Pochechueva と Bovin らはポリアクリル酸を鋳型に用いてい る (47、48)。Jhon と Nagi らはナノスフェアを $\alpha$-L-フコシドと硫 酸基の集積化に利用して有効な P-セレクチンリガンドを調製し た(49)。Palmacci と Seeberger は彼らのモジュラーアプローチを ヘパラン硫酸に対して行っている(50)。これらの研究は我々も 含めて、独自に行われてきたが、単純で効果的な細胞表面糖鎖 ミミックの設計に有用である糖鎖モジュール化法を共通の概念 としているようだ。 


\section{E. Conclusion}

We have described the biological potential of trehalose 1,1-linkages including the galacto-type of trehalose and sulfated sugars such as the 6-O-sulfo-GlcNAc. This means that the apparently complicated oligosaccharide structures can be replaced effectively with simple sugars and functional linkages. For elucidating the key structures and interactions, the concept of key carbohydrate modules and carbohydrate module method provide useful bases and methodologies. They will solve the complexity of cell matrix glycoproteins and glycolipids as well as their diverse biological functions.

\section{E. おわりに}

我々はここまで、ガラクト型糖鎖を含むトレハロース 1,1 結 合糖鎖と、6-O-スルホ GlcNAcのような硫酸化糖の生物的ポテ ンシャルについて述べてきたが、これは明らかに複雑な構造を 持つオリゴ糖鎖が、もつと単純な糖鎖や機能的な結合へと効果 的に置き換えることができることを意味する。鍵となる構造や 相互作用を見出す際、鍵糖鎖モジュールの概念と糖鎖モジュー ル化法が有用な基礎と方法を与えてくれる。これらの方法は細 胞マトリックス上の糖タンパクや糖脂質、そしてその多様化し た生物学的機能の複雑さを解決していくであろう。

\section{References}

1. von Itzstein, M., Wu, W.-Y., Kok, G. B., Pegg, M. S., Dyason, J. C., Jin, B., Phan, T. V., Smythe, M. L., White, H. F., Oliver, S. W., Colman, P. M., Varghese, J. N., Ryan, D. M., Woods, J. M., Bethell, R. C., Hotham, V. J., Cameron, J. M., and Penn, C. R. (1993) Nature 363, 418-423

2. Uzawa, H., Kamiya, S., Minoura, N., Dohi, H., Nishida, Y., Taguchi, K., Yokoyama, S-I., Mori, H., Shimizu, T., and Kobayashi, K. (2002) Biomacromolecules 3, 411-414

3. Miura, Y., Sasao, Y., Kamihira, M., Sakaki, A., Iijima, S., and Kobayashi, K. (2004) Biochim. Biophys. Acta 1673, 131-138

4. Caravano, A., Mengin-Lecreulx, D., Brondello, J-M., Vincent, S. P., and Sinaÿ, P. (2003) Chem. Eur. J. 23, 5888-5898

5. Palomo, C., Oiarbide, M., Landa, A., González-Rego, M. C., García, J. M., González, A., Odriozola, J. M., Martín-Pastor, M., and Linden, A. (2002) J. Am. Chem. Soc. 124, 8637-8643

6. Wellner, E., Gustafsson, T., Bäcklund, J., Holmdahl, R., and Kihlberg, J. (2000) Chem. Bio. Chem. 1, 272-280

7. Sinaÿ, P. (1997) Pure \& Appl. Chem. 69, 459-463

8. Du, Y., and Linhardt, R. J. (1998) Tetrahedron 54, 9913-9959

9. Eisele, T., Toepfer, A., Kretzschmar, G., and Schmidt, R. R. (1996) Tetrahedron Lett. 37, 1389-1392

10. Rich, J. R., and Bundle, D. R. (2004) Org. Lett. 6, 897-900

11. Rye, C. S., and Withers, S. G. (2004) Carbohydr. Res. 339, 699-703

12. Burkart, M. D., Vincent, S. P., Düffels, A., Murray, B. W., Ley, S. V., and Wong, C.-H. (2000) Bioorg. Med. Chem. 8, $1937-1946$

13. Murray, B. W., Wittmann, V., Burkart, M. D., Hung, S.-C., and Wong, C.-H. (1997) Biochemistry 36, 823-831

14. Graves, B. J., Crowther, R. L., Chandran, C., Rumberger, J. M., Li, S., Huang, K.-S., Presky, D. H., Familletti, P. C., Wolitzky, B. A., and Burns, D. K. (1994) Nature 367, 532-538

15. Simanek, E. E., McGarvey, G. J., Jablonowski, J. A., and Wong, C.-H. (1998) Chem. Rev. 98, 833-862

16. Wong, C.-H., Moris-Varas, F., Hung, S.-C., Marron, T. G., Lin, C.-C., Gong, K. W., and Weitz-Schmidt, G. (1997) J. Am. Chem. Soc. 119, $8152-8158$

17. Ikami, T., Kakigami, T., Baba, K., Hamajima, H., Jomori, T., Usui, T., Suzuki, Y., Tanaka, H., Ishida, H., Hasegawa, A., and Kiso, M. (1998) J. Carbohydr. Chem. 17, 453-470

18. Sasaki, K., Nishida, Y., Tsurumi, T., Uzawa, H., Kondo, H., and Kobayashi, K. (2002) Angew. Chem. Int. Ed. 41, 4463-4467

19. Fukunaga, K., Tsukida, T., Moriyama, H., and Kondo, H. (2001) Bioorg. Med. Chem. Lett. 11, 2365-2367

20. Maruta, K., Nakada, T., Kubota, M., Chaen, H., and Sugimoto, T. (1995) Biosci. Biotechnol. Biochem. 59, 1829-1834

21. Tanaka, M., Machida, Y., Niu, S., Ikeda, T., Jana, N. R., Doi, H., Kurosawa, M., Nekooki, M., and Nukina, N. (2004) Nat. Med. 10, 148-154

22. Dolak, L. A., Castle, T. M., and Laborde, A. L. (1980) J. Antibiot. 33, 690-694

23. Wessel, H. P., Tschopp, T. B., Hosang, M., and Iberg, N. (1994) Bioorg. Med. Chem. Lett. 4, 1419-1422

24. Hiruma, K., Kajimoto, T., Weitz-Schmidt, G., Ollmann, I., and Wong, C.-H. (1996) J. Am. Chem. Soc. 118, 9265-9270

25. Nishida, Y., Dohi, H., Uzawa, H., and Kobayashi, K. (1998) Tetrahedron Lett. 39, 8681-8684

26. Dohi, H., Nishida, Y., Mizuno, M., Shinkai, M., Kobayashi, T., Takeda, T., Uzawa, H., and Kobayashi, K. (1999) Bioorg. Med. Chem. 7, 2053-2062

27. Matsuoka, K., Terabatake, M., Esumi, Y., Terunuma, D., and Kuzuhara, H. (1999) Tetrahedron Lett. 40, 7839-7842

28. Watanabe, M., Matsuoka, K., Kita, E., Igai, K., Higashi, N., Miyagawa, A., Watanabe, T., Yanoshita, R., Samejima, Y., Terunuma, D., Natori, Y., and Nishikawa, K. (2004) J. Infect. Dis. 189, 360-368

29. Kitov, P. I., Sadowska, J. M., Mulvey, G., Armstrong, G. D., Ling, H., Pannu, N. S., Read, R. J., and Bundle, D. R. (2000) Nature 403, 669672

30. Dohi, H., Nishida, Y., Tanaka, H., and Kobayashi, K. (2002) Synlett. 39, 8681-8684

31. Hashimoto, S-I., Sakamoto, H., Honda, T., Abe, H., Nakamura, S-I., and Ikegami, S. (1997) Tetrahedron Lett. 38, 8969-8972

32. Nicolaou, K. C., Caulfield, T. J., and Kataoka, H. (1990) Carbohydr. Res. 202, 177-191

33. Koizumi, S., Endo, T., Tabata, K., and Ozaki, A. (1998) Nat. Biotechnol. 16, 847-850

34. Liu, M.-Z., Fan, H.-N., Lee, Y. C. (2001) Biochimie 83, 693-698

35. Dohi, H., Nishida, Y., Furuta, Y., Uzawa, H., Yokoyama, S-I., Ito, S., Mori, H., and Kobayashi, K. (2002) Org. Lett. 4, 355-357

36. Nishida, Y., Wiemann, T., and Thiem, J. (1992) Tetrahedron Lett. 33, 8043-8046

37. Nishida, Y., Tamakoshi, H., Kitagawa, Y., Kobayashi, K., and Thiem, J. (2000) Angew. Chem. Int. Ed. Engl. 39, 2000-2003

38. Nishida, Y., Tamakoshi, H., Kobayashi, K., and Thiem, J. (2001) Org. Lett. 3, 1-3

39. Pratt, M. R., Leigh, C. D., and Bertozzi, C. R. (2003) Org. Lett. 5, 3185-3188 
40. Chaen, H., Nakada, T., Murai, N., Nishimoto, T., Fukuda, S., Sugimoto, T., Kurimoto, M., and Tsujisaka, Y. (2001) J. Appl. Glycosci. 48, 135137

41. Miura, Y., Wada, N., Nishida, Y., Mori, H., and Kobayashi, K. (2004) J. Polym. Sci. Part A: Polym. Chem. 42, 4598-4606

42. Hiruma, K., Kanie, O., and Wong, C.-H. (1998) Tetrahedron 54, 15781-15792

43. Nishida, Y., Uzawa, H., Toba, T., Sasaki, K., Kondo, H., and Kobayashi, K. (2000) Biomacromolecules 1, 68-74

44. Schwörer, R., and Schmidt, R. R. (2002) J. Am. Chem. Soc. 124, 1632-1637

45. Sasaki, K., Nishida, Y., Uzawa, H., and Kobayashi, K. (2003) Bioorg. Med. Chem. Lett. 13, 2821-2823

46. Pan, K.-M., Baldwin, M., Nguyen, J., Gasset, M., Serban, A., Groth, D., Mehlhorn, I., Huang, Z., Fletterick, R. J., Cohen, F. E., and Prusiner, S. B. (1993) Proc. Natl. Acad. Sci. USA 90, 10962-10966

47. Patel, A., and Lindhorst, T. K. (2001) J. Org. Chem. 66, 2674-2680

48. Pochechueva, T. V., Galanina, O. E., Bird, M. I., Nifantiev, N. E., and Bovin, N. V. (2002) Chem. Biol. 9, 757-762

49. John, A. E., Lukacs, N. W., Berlin, A. A., Palecanda, A., Bargatze, R. F., Stoolman, L. M., and Nagy, J. O. (2003) FASEB J. 17, 2296-2298

50. Palmacci, E. R., and Seeberger, P. H. (2004) Tetrahedron 60, 7755-7766

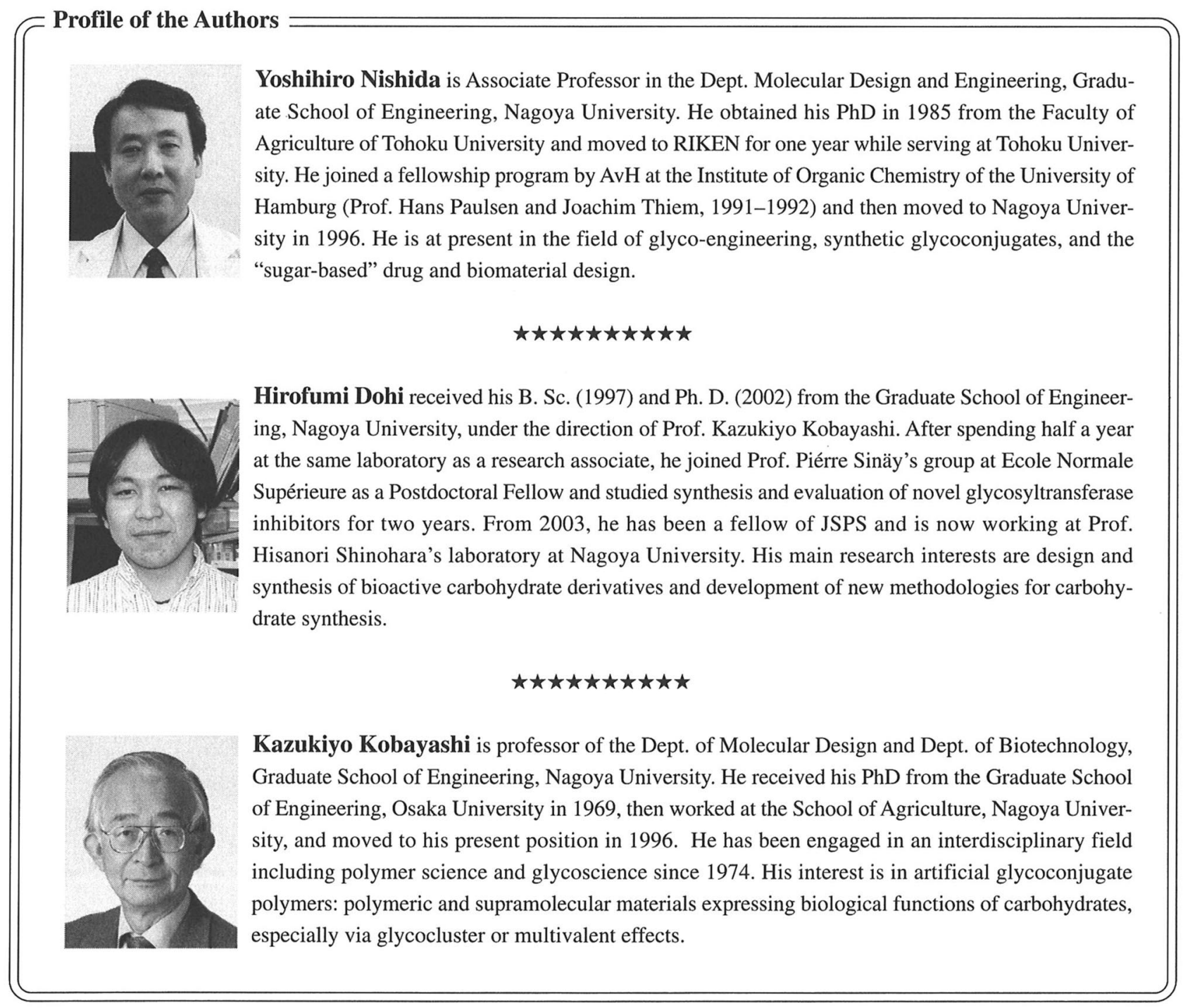

